\title{
Persons with Disabilities (PWD) and Poverty in Indonesia
}

\author{
Adrianna Bella ${ }^{a}$ \\ Teguh Dartanto ${ }^{\mathrm{b}}$ \\ Universitas Indonesia
}

\begin{abstract}
There is an urgent need to provide an evidence-based study to support and mainstream PWD on the development agenda in Indonesia due to low prioritisation of poverty eradication of PWD. Thus, this study aims at examining the impacts of disability, types of disability and causes of disability on household's poverty status and household's poverty gap index. Applying Logistic and Tobit regressions, this study confirmed that disabled-headed households are more likely to become poor by 1.3 percentage points and have deeper poverty gap index by 2.6 percent. Household with a visually impaired household head is less likely to be poor compared to other disabled-headed households, while one that has a household head with self-care problem tends to have higher probability of falling into poverty. Moreover, a household in which the household head has congenital disability (disability at birth) has higher probability of being poor by 4.8 percentage points and has deeper poverty gap index of about 7.8 percent.
\end{abstract}

Keywords: Inclusive development, Indonesia, persons with disabilities, poverty JEL classification: 131, 132, J14

\section{Introduction}

Persons with Disabilities (henceforth PWD) are the world's largest and one of the most disadvantaged minority: 20 percent of the world's poorest population are disabled, 98 percent of children with disabilities in developing countries do not attend school, and literacy rate for adults with disabilities is as low as 3 percent (Byrnes et al., 2007). The World Health Organization (WHO, 2011) reported that PWD make up nearly 15 percent of the global population; therefore, without involving them in development, progress in poverty reduction is severely hindered. The conditions of PWD may appear due to some discrimination, such as institutional discrimination, physical environment discrimination, and social discrimination (Yeo \& Moore, 2003). The discrimination results in exclusion of PWD from education, employment, legal processes and even healthcare. As a result, PWD are more likely to have a lower socioeconomic status compared to other groups.

a Institute for Economic and Social Research, Faculty of Economics and Business, Universitas Indonesia, Campus UI Salemba, JI. Salemba Raya No. 4, Jakarta, 10430, Indonesia. Email: adrianna_bella@hotmail.com

b Department of Economics, Faculty of Economics and Business, Universitas Indonesia, Campus UI Depok, Depok, 16424, Indonesia. The author is also affiliated to the Institute for Economic and Social Research of the same university. Email: teguh.dartanto@ui.ac.id (Corresponding author)

* The authors thank the referee(s) for valuable comments that improve the quality of this article. We also thank LPEM FEB UI and the 2017 PITTA Grant of Universitas Indonesia for the financial support to conduct this research. All remaining errors are our responsibility.

Article Info: Received 13 July 2017; Revised 1 June 2018; Accepted 9 August 2018

https://doi.org/10.22452/MJES.vol55no2.2 
The ignorance and neglect of government and society concerning PWD often result in these individuals experiencing lower social and economic conditions (Byrnes et al., 2007). Studies and statistics have shown that the poverty rate of PWD is higher than that of non-disabled people (Burkhauser, Houtenville, \& Rovba, 2005; Lamichhane, Paudel, \& Kartika, 2014; McNeil, 2001). Not only do PWD face multiple disadvantages, but they also possess lower capabilities compared to non-disabled people - all these are factors that contribute to PWD having lower social and economic status. However, the disparity does not appear only between these two groups, but also among PWDs. Studies by Gouvier, Mayville and Sytsma-Jordan (2003), Kavanagh et al. (2015) and Smith (2007) found that different types of disabilities might lead to different socioeconomic conditions. Other studies by Bordieri and Drehmer (1988) and Florian (1978) found that different causes of disabilities affect job enrolment, which serves to differentiate their economic conditions. The different characteristics of PWD call for customised policies to eradicate poverty of PWD, as poverty alleviation policies for nondisabled people are probably not effective when implemented to PWD.

In the case of Indonesia, the National Socioeconomic Survey (SUSENAS) 2012 shows that under the national poverty line, the poverty rate of PWD is 13.86 percent, while the poverty rate of non-disabled people is only 12.86 percent. Indonesia, unfortunately, has not implemented significant actions to improve the condition of PWD, even after ratification of the Convention on the Rights of Persons with Disabilities (CRPD) with Law No.19/2011. According to Harahap and Bustanuddin (2015), the Indonesian government still has little intention to synchronise or harmonise CRPD to every valid legal instruments in Indonesia, such as traffic laws, officialdom laws, health laws, employment laws, construction/structure laws, and others.

Even though around six million (2.45 percent of Indonesia's total population) are categorised as PWD, policy discussions and the designing of poverty alleviation programs of PWD in Indonesia are always lagging behind. One of the main reasons for the low prioritisation of disability issues is the lack of data. Consequently, the study on disabilities and poverty has remained a peripheral topic of research. Moreover, empirical studies of the impacts of disabilities on poverty and poverty alleviation of PWD are relatively scarce and have little variation in methodologies (for instance, see Adioetomo, Mont, \& Irwanto, 2014; Halimatussadiah, Agriva, \& Nuryakin, 2015). This low number of evidence-based researches may lead to little support and attention to PWD in Indonesia.

There is an urgent need to conduct a solid and rigorous study to support and mainstream PWD on the development agenda in Indonesia due to the fact that PWD is a part of the Sustainable Development Goals - the new world development agenda. This study aims at contributing to three main issues: first, examining the relationship between disability and poverty in Indonesia - whether disabled people are more likely to become poor or not; second, assessing the impacts of types and causes of disabilities on the poverty status of PWD; third, examining the relationship between disabilities and the intensity of poverty (the depth of poverty measured by the gap between expenditure/income and the poverty line). Even though both PWD and non-disabled people are categorised as poor, PWD might have a higher intensity of poverty due to more severe discriminations and other various obstacles. This research 
not only contributes to the literature, but it also contributes to understanding of the relationship between poverty and disability and designing of effective policies to help PWD get out of poverty.

This study will start with a literature review, focusing mainly on how disabilities relate to poverty. The next section will explain research methodologies including logistic and Tobit regression as well as poverty calculation; data and statistical facts about disabilities will also be discussed. The paper will then analyse the impact of disabilities on poverty and depth of poverty. The study ends with some important findings and policy recommendations.

\section{Literature Review}

\subsection{Capability Approach: Earning and Conversion Handicap}

According to Sen's capability approach theory (1993, 2000, 2009), people with disabilities are more likely to become poor due to a couple of disadvantages, which are 'the earning handicap' and 'the conversion handicap.' The earning handicap is the impairment of income-earning ability. For example, a visually impaired person cannot read or walk in the same way a person without disabilities can; this affects the blind individual's ability to accomplish certain tasks. As such, the individual is restricted in his/her choice of jobs when compared to the non-disabled and this will affect his/her potential income. The conversion handicap is the difficulty in converting incomes and resources into good living due to disability. According to Mitra, Posarac and Vick (2011), the conversion handicap is the extra need and cost needed in order to achieve the same level of advantage or well-being as the others as a result of disabilities. Consequently, PWD may experience lower standard of living than their non-disabled counterparts with the same level of income (Zaidi \& Burchardt, 2003). The earning handicap and conversion handicap are shown in Figure 1.

Based on Mitra, Posarac and Vick (2011), the earning handicap causes PWD to have a lower capability set (choices of commodity to reach functioning) than non-disabled people. On the other hand, the conversion handicap causes PWD who have the same capability as non-disabled individuals to not have the same functioning due to the cost of disability. These disadvantages of PWD make them have lower capability, which will

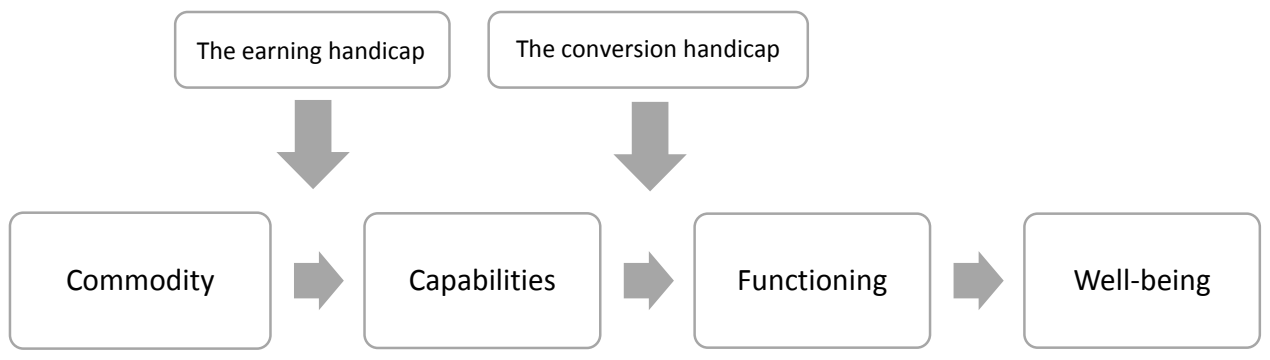

Figure 1. Framework of capability approach in case of disability Source: Adapted from Sen's Capability Approach 
further lower the outcome of functioning and well-being. Based on Sen's capability approach, people with disabilities are more vulnerable to become poor. This framework is the foundation for the research conducted in this study.

\subsection{Previous Studies: Disability and Poverty}

Benfield (2008) found disability to have a significant positive relation with poverty. Similarly, Kavanagh et al. (2015) found that PWD have higher disadvantages in all socioeconomic indicators, including income, compared to non-disabled individuals. Other studies also found that PWD have higher poverty rate when compared with nondisabled people, which means that PWD are more likely to become poor. Lamichhane, Paudel and Kartika (2014) found that the poverty rate of PWD is 28.6 percent, while poverty rate of non-disabled people is 26.6 percent. In the same vein, McNeil (2001) found that the poverty rate of people with severe disabilities, which is 27.9 percent, is much higher than that of non-disabled people, which is only 8.3 percent.

Many studies confirmed that different types and causes of disabilities have different effects on the socioeconomic status of PWD, including income and poverty status. Smith (2007) discovered that PWD who need assistance in personal care and routine needs are more likely to be unemployed compared to those who do not. Gouvier, Mayville and Sytsma-Jordan (2003) found that among PWD job seekers, those with physical disabilities have a higher rate of employability than those with mental disabilities. Bordieri and Drehmer (1988) and Kavanagh et al. (2015) also discovered that people with psychological disabilities have the biggest socioeconomic disadvantages (low education, low income, unpaid worker, and housing vulnerability) compared to those with other types of disabilities. Florian (1978) also found that PWD whose cause of disability is in him/herself have lower probability of being employed, and those whose cause of disability is external and out of their control are more likely to be employed - as a compensation for their disability.

In the case of Indonesia, Adioetomo, Mont and Irwanto (2014) using a descriptive analysis of census data 2010 found that persons with disabilities in Indonesia are less likely to attend school and to be employed. Moreover, people with disabilities were 30 to 50 percent more likely to be poor than non-disabled people, especially in urban areas. In contrast, Halimatussadiah, Agriva and Nuryakin (2015) using Census 2010 and Susenas 2012 showed lower unemployment rate of PWD compared with persons without disabilities (PWOD). This finding seems to contradict international evidence. They argued that discouraged workers are behind the low unemployment rate of PWD.

\section{Research Method}

\subsection{Empirical Model}

This study uses the 2012 third quarter National Social Economic Survey (SUSENAS) by Central Statistical Agency of Indonesia (BPS). The survey, covering all provinces, contains two main datasets: Core and Module. Core recorded basic characteristics of 71,803 households containing 277,854 individuals, such as demography, education, 
job, asset, etc. Meanwhile, Module covered additional information of the households and individuals on a subset of the Core, such as disability characteristics, social capital, measure of happiness, household expenditure, etc. Having omitted the missing, 71,722 households containing 277,576 individuals are included in this study.

Since expenditure and poverty status data are collected on household basis, we conduct analysis on household basis by using household head's and household's data. The individual data (such as disability condition, education, etc.) is collected from household head's information, while the collective data (such as housing status, social capital, etc.) is taken from household's information.

We analysed two samples. The first sample contains 71,722 households including both disabled and non-disabled-headed households to examine whether disabled people are more likely to become poor or not and examine whether disabled people have a higher intensity of poverty. The second is a sub-sample of the first, containing 3,596 disabled-headed households. The goal of analysing the sub-sample is to assess what types and causes of disabilities affect the poverty status of PWD.

We then proposed four econometric models to examine the relationship between disability and poverty and to assess the effect of different types and causes of disability on the poverty status of PWD. This study then examines both issues: 1) the relationship between disability and poverty status, and 2) the effect of disability on the intensity of poverty indicated by the poverty gap index. Models 1 and 2 econometrically estimate the impacts of disability on the poverty status of households and the poverty gap index respectively. Models 3 and 4 observe the effect of the types and causes of disabilities on the poverty status and the poverty gap index. Unlike in previous studies such as Adioetomo, Mont and Irwanto (2014) and Halimatussadiah, Agriva and Nuryakin (2015), this study clearly examines the effects of different types and causes of disability on the poverty status, so that we can have a better targeting policy for PWD.

Estimation methods used in this paper are binary response regression for Logistic model and limited dependent variable regression for Tobit model. Binary response regression is a qualitative response regression in which the dependent variable is of the yes/no or presence/absence type (Gujarati \& Porter, 2009). Meanwhile, limited dependent variable regression, or usually called censored regression, is observed only if a certain condition is met. The software used to analyse these two regression models is Stata 13. The limited dependent model including Logit, Probit and Tobit is estimated using maximum likelihood estimation (MLE). The MLE method is to estimate parameters that attempt to find values that maximize the likelihood function, given the observations (for details, see Gujarati \& Porter, 2009).

This study uses Logistic (Logit) model to estimate Models 1 and 3 while Tobit model is used to estimate Models 2 and 4. The application of Logit model is due to binary dependent variables in Models 1 and 3 (Gujarati \& Porter, 2009). The Logistic model that measures the probability of being poor refers to some studies about poverty, such as Benfield (2008) and Sekhampu (2013), in which " 1 " is considered as poor and " 0 " is considered as non-poor. Based on Gujarati \& Porter (2009), Tobit model is the best model to analyse the data which needs censoring, such as poverty gap. Tobit model, with poverty gap as the dependent variable, refers to previous studies such as Asogwa, Umeh and Okwoche (2012) and Etim, Edet and Esu (2009). 
A Logit model is used to establish the likelihood of household being poor with binary variable $y$. This model then can be derived from latent variable model with unobserved variable or latent variable $y^{*}$, where those who have larger values of $y^{*}$ are observed as $y=1$, while those with smaller values of $\mathrm{y}^{*}$ are observed as $\mathrm{y}=0$ (Long, 1997). The latent $y^{*}$ is assumed to be linearly related to the observed $x$ through the following model:

$$
y_{i}^{*}=x_{i} \beta+\varepsilon_{i}
$$

where $x_{i}$ is the independent variable, $\beta$ is the parameter and $\varepsilon_{i}$ is the error term. The latent variable $\mathrm{y}^{*}$ is linked to the observed binary by the measurement equation:

$$
y_{i}=\left\{\begin{array}{l}
1 \text { if } y_{i}^{*}>\tau \\
0 \text { if } y_{i}^{*} \leq \tau
\end{array}\right.
$$

where $\tau$ is the threshold or cut off point. If $\mathrm{y}^{*} \leq \tau$ then $\mathrm{y}=0$ and if $\mathrm{y}^{*}>\tau$, then $\mathrm{y}=1$. In this case, $\tau$ stands for poverty line. Then, let $P_{i}$ denote the probability that $i$ th household is below the poverty line (poor), so that:

$$
P_{i}=\frac{e^{y}}{1+e^{y}}
$$

Equation (3) is the logistic distribution function for the probability of being poor. Dividing the probability of being poor by the probability of not being poor will generate an odds ratio. Logistic model (L) is simply natural log of odds ratio, which can be written as follows:

$$
L_{i}=\ln \left(\frac{P_{i}}{1-P_{i}}\right)=y_{i}
$$

Tobit model is useful for analysing censored sample in which sample information is available only for some observations (Gujarati \& Porter, 2009). The Tobit model can be expressed as:

$$
\begin{aligned}
Y_{i} & =x_{i} \beta+u_{i} & & \text { if } x_{i} \beta+u_{i}>0 \\
& =0 & & \text { otherwise. }
\end{aligned}
$$

where $Y_{i}$ is the dependent variable, $x_{i}$ is the independent variable, $\beta$ is the parameter, and $u_{i}$ is the error term.

The explanatory variables, especially for control variables, are based on studies such as Benfield (2008), Benson, Chamberlin and Rhinehart (2005), Dartanto and Nurkholis (2013), and Lamichhane, Paudel and Kartika (2014). The explanatory variables are divided into three categories: disability characteristics, household characteristics, and household head characteristics. Household and household head characteristics are identical for every model, while disability characteristics differ: first and second models use disability status, while third and fourth models use types of disability and causes of disability as representations of disability characteristics. 
A total of four models are considered. The econometric models of Logit and Tobit models are as follows:

Model 1 and Model 3 (Logit model):

$P_{i}^{0}=\alpha+\sum_{j=1}^{J} \beta_{j} \operatorname{Dis}_{\text {Char } j i j_{i j}}+\sum_{k=1}^{K} \gamma_{k} H H_{\text {Char }_{k i}}+\sum_{l=1}^{L} \theta_{l} H H H_{\text {Char }_{i j}}+u_{i}$

Model 2 and Model 4 (Tobit model):

$$
P_{j}^{1}=\alpha+\sum_{m=1}^{M} \beta_{m} \operatorname{Dis}_{\text {Char }_{m j}}+\sum_{n=1}^{N} \gamma_{n} H H_{\text {Char } r_{j}}+\sum_{o=1}^{o} \theta_{o} H H H_{\text {char o }}+u_{j}
$$

where:

- $\quad P_{i}^{0}$ is household's poverty status; $0=$ non-poor and 1=poor;

- $P_{j}^{1}$ is household's poverty gap;

- Dis $_{\text {char }}$ is a vector of disability characteristics $(j=1,2, \ldots, J \& m=1,2, \ldots, M)$, which are disability status for first and second model and types \& causes of disability for third and fourth model;

- $\quad H H_{\text {char }}$ is a vector of household characteristics $(k=1,2, \ldots, K \& n=1,2, \ldots, N)$, including social capital, household size, and location of household;

- $H H H_{\text {char }}$ is a vector of household head characteristics $(I=1,2, \ldots, L \& 0=1,2, \ldots, 0)$, including gender, age, and marital status of household head;

- $u$ is error term;

- $\quad i$ is an individual observation of Logit model, $\mathrm{i}=1,2,3, \ldots, 71,722$; and

- $j$ is an individual observation of Tobit model, $i=1,2,3, \ldots, 3,596$.

Table 1 lists the variables that are included in each of the four models.

Table 1. List of variables used in each model

\begin{tabular}{|c|c|c|c|c|}
\hline Variable & $\begin{array}{c}\text { Model } 1 \\
\text { (sample: all } \\
\text { households) }\end{array}$ & $\begin{array}{c}\text { Model } 2 \\
\text { (sample: all } \\
\text { households) }\end{array}$ & $\begin{array}{c}\text { Model } 3 \\
\text { (sample: disabled- } \\
\text { headed households) }\end{array}$ & $\begin{array}{c}\text { Model } 4 \\
\text { (sample: disabled- } \\
\text { headed households) }\end{array}$ \\
\hline \multicolumn{5}{|l|}{ Disability characteristics (Dis $s_{\text {char }}$ ) } \\
\hline $\begin{array}{l}\text { Household head with PWD } \\
\qquad(1=y e s, 0=\text { others })\end{array}$ & $\checkmark$ & $\checkmark$ & & \\
\hline \multicolumn{5}{|l|}{ Types of disability } \\
\hline $\begin{array}{l}\text { Visual impairment } \\
\qquad(1=\text { yes, } 0=\text { others })\end{array}$ & & & $\checkmark$ & $\checkmark$ \\
\hline $\begin{array}{l}\text { Hearing or communication } \\
\text { disorder ( } 1=\text { yes, } 0=\text { others) }\end{array}$ & & & $\checkmark$ & $\checkmark$ \\
\hline $\begin{array}{l}\text { Concentration problems } \\
\text { (1=yes, } 0=\text { others })\end{array}$ & & & $\checkmark$ & $\checkmark$ \\
\hline $\begin{array}{l}\text { Walking problems } \\
\qquad(1=\text { yes, } 0=\text { others })\end{array}$ & & & $\checkmark$ & $\checkmark$ \\
\hline $\begin{array}{l}\text { Personal care problems } \\
\qquad(1=\text { yes, } 0=\text { others })\end{array}$ & & & $\checkmark$ & $\checkmark$ \\
\hline
\end{tabular}


Table 1. (continued)

\begin{tabular}{|c|c|c|c|c|}
\hline Variable & $\begin{array}{l}\text { Model } 1 \\
\text { (sample: all } \\
\text { households) }\end{array}$ & $\begin{array}{c}\text { Model } 2 \\
\text { (sample: all } \\
\text { households) }\end{array}$ & $\begin{array}{c}\text { Model } 3 \\
\text { (sample: disabled- } \\
\text { headed households) }\end{array}$ & $\begin{array}{c}\text { Model } 4 \\
\text { (sample: disabled- } \\
\text { headed households) }\end{array}$ \\
\hline \multicolumn{5}{|l|}{ Causes of disability } \\
\hline Congenital ( $1=y e s, 0=$ others) & & & $\checkmark$ & $\checkmark$ \\
\hline $\begin{array}{l}\text { Accident/disaster } \\
\qquad(1=\text { yes, } 0=\text { others })\end{array}$ & & & $\checkmark$ & $\checkmark$ \\
\hline $\begin{array}{l}\text { Pressure/stress } \\
\qquad(1=\text { yes, } 0=\text { others })\end{array}$ & & & $\checkmark$ & $\checkmark$ \\
\hline \multicolumn{5}{|l|}{$\begin{array}{l}\text { Household characteristics } \\
\left(H H_{\text {char }}\right)\end{array}$} \\
\hline Social capital & $\checkmark$ & $\checkmark$ & $\checkmark$ & $\checkmark$ \\
\hline Size of household member & $\checkmark$ & $\checkmark$ & $\checkmark$ & $\checkmark$ \\
\hline Location (1=rural, $0=$ =urban) & $\checkmark$ & $\checkmark$ & $\checkmark$ & $\checkmark$ \\
\hline Electricity ( $1=y e s, 0=$ no access) & $\checkmark$ & $\checkmark$ & $\checkmark$ & $\checkmark$ \\
\hline $\begin{array}{l}\text { House ownership } \\
\qquad(1=\text { self-owned, } 0=\text { others })\end{array}$ & $\checkmark$ & $\checkmark$ & $\checkmark$ & $\checkmark$ \\
\hline \multicolumn{5}{|l|}{$\begin{array}{l}\text { Household head characteristics } \\
\left(H H H_{\text {char }}\right)\end{array}$} \\
\hline Gender ( $1=$ female, $0=$ others $)$ & $\checkmark$ & $\checkmark$ & $\checkmark$ & $\checkmark$ \\
\hline Age & $\checkmark$ & $\checkmark$ & $\checkmark$ & $\checkmark$ \\
\hline $\begin{array}{l}\text { Marital status } \\
\quad(1=\text { married, } 0=\text { others })\end{array}$ & $\checkmark$ & $\checkmark$ & $\checkmark$ & $\checkmark$ \\
\hline Years of schooling & $\checkmark$ & $\checkmark$ & $\checkmark$ & $\checkmark$ \\
\hline
\end{tabular}

Source: Authors.

A household head is considered as a disabled person if he/she meets one of the disability categories. The categories of disabilities used in this study are visual impairment, hearing or communication disorder, concentration problem, walking problem, and personal care problem. The descriptions of each category based on the Indonesian National Social Economic Survey (SUSENAS) are as follows:

- Visual impairment is inability to see even after using glasses, such as low vision, colour-blind, stone-blind, etc.

- Hearing disorder is inability to hear even after using hearing equipment, such as deaf.

- Communication disorder is inability to communicate with others, such as speech impairment.

- Concentration problem is disability to remember or concentrate, such as autism, retardation, mental disorder, etc.

- Walking problem is disability to walk or climb up stairs, such as leg paralysis, disproportionate size of legs, etc. 
- Personal care problem is self-care disability, such as eating, bathing, dressing up, etc.

Causes of disability used in this study are disabilities at birth, accident/disaster, life pressure/stress and disease. As each of these variables are mutually exclusive, there is a reference group for each categorical variable, which is 'disability caused by disease'.

\subsection{Poverty Calculation}

This study uses the Foster-Greer-Thorbecke (FGT) (1984) method to measure poverty. This method is also used by the Indonesian Central Statistical Agency, so that the result of this study will be comparable and applicable in Indonesia. The FGT is as follows:

$$
P_{\alpha}=\frac{1}{n} \sum_{i=1}^{q}\left(\frac{z-y_{i}}{z}\right)^{\alpha}
$$

where:

$\alpha=$ FGT Measures of Poverty; $\alpha=0$ is headcount index (poverty index); $\alpha=1$ is to calculate the poverty gap index, and $\alpha=2$ is the squared poverty gap index.

$z=$ Poverty line.

$y_{i}=$ Average monthly per capita expenditure of people below poverty line $(i=1,2, \ldots, q)$.

$q=$ Number of people whose expenditure are below poverty line.

$n=$ Total number of people.

Data on expenditure by the Indonesia Central Bureau of Statistics (BPS) are collected at household level. However, the poverty line made by BPS and poverty calculation are measured in per capita level (individual level). Thus, the poverty rate and poverty gap calculated in FGT measurement is determined at an individual level. After calculating poverty rate and poverty gap, we grouped them in matched samples: all households and disabled-headed households.

The definition of poverty used in this study is based on the description of Indonesia Central Bureau of Statistics (BPS), which is the inability to suffice people's minimum basic needs like food, clothes, health, housing and education (Badan Pusat Statistik, 2014). The minimum basic needs to form households' poverty status (poor and nonpoor) are built upon Indonesia's poverty line in September 2012 issued by Indonesia Central Bureau of Statistics (BPS) in all urban and rural areas of Indonesia's 33 provinces. Poverty status then belongs to households and affects the economic status of household's members afterwards.

Poverty line $(z)$ is a combination between food and non-food poverty line which varies in each province (Badan Pusat Statistik, 2017). People whose per capita expenditure is under the poverty line are categorised as poor people. Food poverty line is minimum expenditure to fulfil 2,100 kcal per day (which includes 52 food commodities), while non-food poverty is minimum expenditure to cover minimum needs of housing, clothing, education and health (which contains 52 non-food commodities in urban areas and 47 non-food goods in rural areas). 
The first step to calculate poverty line is to define food poverty line, which can be measured by the following formula:

$$
G K M_{j p}^{*}=\sum_{k=1}^{52} P_{j k p} \cdot Q_{j k p}=\sum_{k=1}^{52} V_{j k p}
$$

where:

$G K M_{j p}^{*}$ is food poverty line of area $j$ (before being converted into 2,100 kcal) of province $p$ $P_{j k p}$ is average price of commodity $k$ in area $j$ and province $p$

$Q_{j k p}$ is average quantity of commodity $k$ in area $j$ and province $p$

$j$ is area (rural or urban)

$p$ is province

The calculated food poverty line is then converted into 2,100 kcal by multiplying 2,100 with average calories' implicit price in area $j$ (from reference residents). The formula is as follows:

$$
H K_{j p}=\frac{\sum_{k=1}^{52} V_{j k p}}{\sum_{k=1}^{52} K_{j k p}}
$$

where:

$K_{j k p}$ is calories from commodity $k$ in area $j$ of province $p$

$H K_{j p}$ is average price of calories in area $j$ of province $p$

The next step is measuring non-food poverty line which can be formulated as follows:

$$
\operatorname{GKNM}_{j p}=\sum_{k=1}^{n} \gamma_{k j} \cdot V_{k j p}
$$

where:

$G K N M_{j p}$ is non-food poverty line in area $j$ and province $p$

$\gamma_{k j}$ is expenditure of each commodity / non-food category in area $j$ and province $p$

$V_{k j p}$ is ratio of commodity expenditure / non-food category in area $j$ and province $p$

$k$ is non-food commodity

$j$ is area (rural or urban)

$p$ is province

The two poverty lines, which are food and non-food ones, are combined to create poverty line. In other words, poverty line can be calculated as:

$$
\mathrm{GK}=\mathrm{GKM}+\mathrm{GKNM}
$$

where:

GK is poverty line

GKM is food poverty line

GKNM is non-food poverty line

Poverty line used in this study, along with the calculated poverty rate and poverty gap, is depicted in Table 2. 
Table 2. Poverty line, poverty rate, and poverty gap in each province

\begin{tabular}{|c|c|c|c|c|c|c|}
\hline \multirow[b]{2}{*}{ Province } & \multicolumn{3}{|c|}{ Rural } & \multicolumn{3}{|c|}{ Urban } \\
\hline & $\begin{array}{c}\text { Poverty line } \\
\text { (Sept. 2012) (Rp) }\end{array}$ & $\begin{array}{l}\text { Poverty } \\
\text { rate (\%) }\end{array}$ & $\begin{array}{l}\text { Poverty } \\
\text { gap (\%) }\end{array}$ & $\begin{array}{c}\text { Poverty line } \\
\text { (Sept. 2012) (Rp) }\end{array}$ & $\begin{array}{l}\text { Poverty } \\
\text { rate (\%) }\end{array}$ & $\begin{array}{l}\text { Poverty } \\
\text { gap (\%) }\end{array}$ \\
\hline Aceh & 310,089 & 19.35 & 3.60 & 352,056 & 11.82 & 1.25 \\
\hline North Sumatera & 249,165 & 16.33 & 2.81 & 295,080 & 9.49 & 1.72 \\
\hline West Sumatera & 273,655 & 9.70 & 1.58 & 321,128 & 4.30 & 0.68 \\
\hline Riau & 295,582 & 7.85 & 1.04 & 333,933 & 5.42 & 0.75 \\
\hline Jambi & 248,812 & 7.59 & 1.02 & 328,504 & 10.20 & 2.28 \\
\hline South Sumatera & 238,901 & 13.32 & 1.62 & 296,933 & 14.36 & 2.25 \\
\hline Bengkulu & 267,273 & 18.17 & 3.14 & 318,881 & 14.97 & 2.61 \\
\hline Lampung & 251,202 & 16.60 & 2.64 & 297,421 & 10.91 & 1.29 \\
\hline Bangka Belitung Islands & 390,294 & 8.61 & 1.27 & 374,284 & 3.91 & 0.35 \\
\hline Riau Islands & 316,963 & 6.63 & 0.59 & 373,725 & 8.05 & 0.92 \\
\hline DKI Jakarta & - & - & - & 392,571 & 3.94 & 0.67 \\
\hline West Java & 228,577 & 11.47 & 1.91 & 249,170 & 8.20 & 1.32 \\
\hline Central Java & 223,622 & 17.36 & 2.86 & 245,817 & 12.48 & 1.96 \\
\hline DI Yogyakarta & 241,975 & 21.57 & 4.42 & 284,549 & 14.70 & 2.53 \\
\hline East Java & 234,556 & 18.02 & 2.68 & 253,947 & 8.64 & 1.26 \\
\hline Banten & 228,794 & 8.58 & 1.01 & 262,371 & 3.64 & 0.62 \\
\hline Bali & 230,389 & 4.29 & 0.41 & 270,020 & 3.55 & 0.43 \\
\hline West Nusa Tenggara & 230,054 & 17.37 & 2.50 & 274,879 & 18.66 & 4.08 \\
\hline East Nusa Tenggara & 205,083 & 23.09 & 3.91 & 293,906 & 10.30 & 1.88 \\
\hline West Kalimantan & 232,303 & 9.06 & 1.30 & 254,972 & 4.29 & 0.73 \\
\hline Central Kalimantan & 279,008 & 5.35 & 0.81 & 274,222 & 4.53 & 1.00 \\
\hline South Kalimantan & 257,282 & 5.73 & 0.99 & 286,844 & 3.05 & 0.31 \\
\hline East Kalimantan & 330,329 & 9.42 & 1.36 & 384,413 & 4.26 & 0.71 \\
\hline North Sulawesi & 217,355 & 8.57 & 1.28 & 231,794 & 6.67 & 1.05 \\
\hline Central Sulawesi & 258,393 & 16.41 & 2.97 & 292,578 & 8.79 & 1.93 \\
\hline South Sulawesi & 183,959 & 13.45 & 2.39 & 215,790 & 3.55 & 0.42 \\
\hline Southeast Sulawesi & 198,902 & 16.67 & 2.67 & 215,050 & 2.53 & 0.12 \\
\hline Gorontalo & 210,101 & 23.68 & 4.27 & 217,073 & 4.96 & 0.62 \\
\hline West Sulawesi & 205,383 & 11.54 & 1.26 & 212,579 & 9.02 & 1.95 \\
\hline Maluku & 284,629 & 29.72 & 6.08 & 314,855 & 8.56 & 1.68 \\
\hline North Maluku & 240,447 & 8.39 & 1.03 & 276,117 & 2.04 & 0.05 \\
\hline West Papua & 346,157 & 43.76 & 10.06 & 374,382 & 4.16 & 0.64 \\
\hline Papua & 281,022 & 43.15 & 10.80 & 344,415 & 7.83 & 1.46 \\
\hline
\end{tabular}

Source: Badan Pusat Statistik (2017) and authors' calculation. 


\section{Analysis of Results}

\subsection{Descriptive Analysis}

The physical condition of individuals can be classified as having disabilities and not having one. Meanwhile, households can be divided into two common economic conditions: poor and non-poor. This descriptive analysis combines these two categories of households and individuals by segregating data into four categories: poor disabledheaded household, non-poor disabled-headed household, poor non-disabled-headed household and non-poor non-disabled-headed household. Moreover, independent variables are grouped into three categories: disability characteristics, household characteristics and household head characteristics. There is also an additional depiction of government's social assistance performance for PWD and non-disabled people.

As seen briefly in Table 3, the socioeconomic conditions of non-poor households are better than those of poor households. Comparing disabled-headed households and non-disabled-headed households, socioeconomic conditions of non-disabled-headed households are slightly better than those of disabled-headed households. Among households with disabled household head, both poor ones and non-poor ones have more household heads with visual impairment and hearing or communication disorder. Moving on to causes of disability, poor disabled-headed households have more heads of household with disabilities at birth that the non-poor ones.

In household characteristics, average values of social capital of PWD are lower than the non-disabled one. This early sign may explain the social discrimination experienced by PWD (Yeo \& Moore, 2003). For both poor and non-poor status, PWD are more likely to live in rural areas compared to non-disabled people. In terms of household head characteristics, disabled household heads are on average older than non-disabled household heads. Such a difference may exist because the probability of being disabled increases as one's age increases due to illness, accident, etc. Both poor and non-poor non-disabled people have higher years of education than those of PWD. The higher education of non-disabled people may then lead to higher income and better economic status.

The presence of government assistance is supposed to examine the treatment of poverty for PWD and non-disabled people. Table 3 shows that government assistance, especially for the poor, is not very different between PWD and non-disabled people. For instance, around 74 percent of poor PWD received rice for the poor (Raskin) within the last three months, while around 73 percent of poor non-disabled household received Raskin. This indicates that the government of Indonesia still applies equal treatment to overcome the problem of poverty of PWD and non-disabled people. Meanwhile, PWD have several disadvantages that are not experienced by nondisabled people. Thus, the treatment of poverty alleviation for PWD and non-disabled people should be different and modified due to the special conditions faced by PWD. One thing that should be emphasised is that justice does not always mean equality, because different people have different needs. However, government assistance is not included as an independent/exploratory variable in the regression model due to an endogeneity problem: the poverty status of households causes the receipt of government assistance. 
Persons with Disabilities (PWD) and Poverty in Indonesia

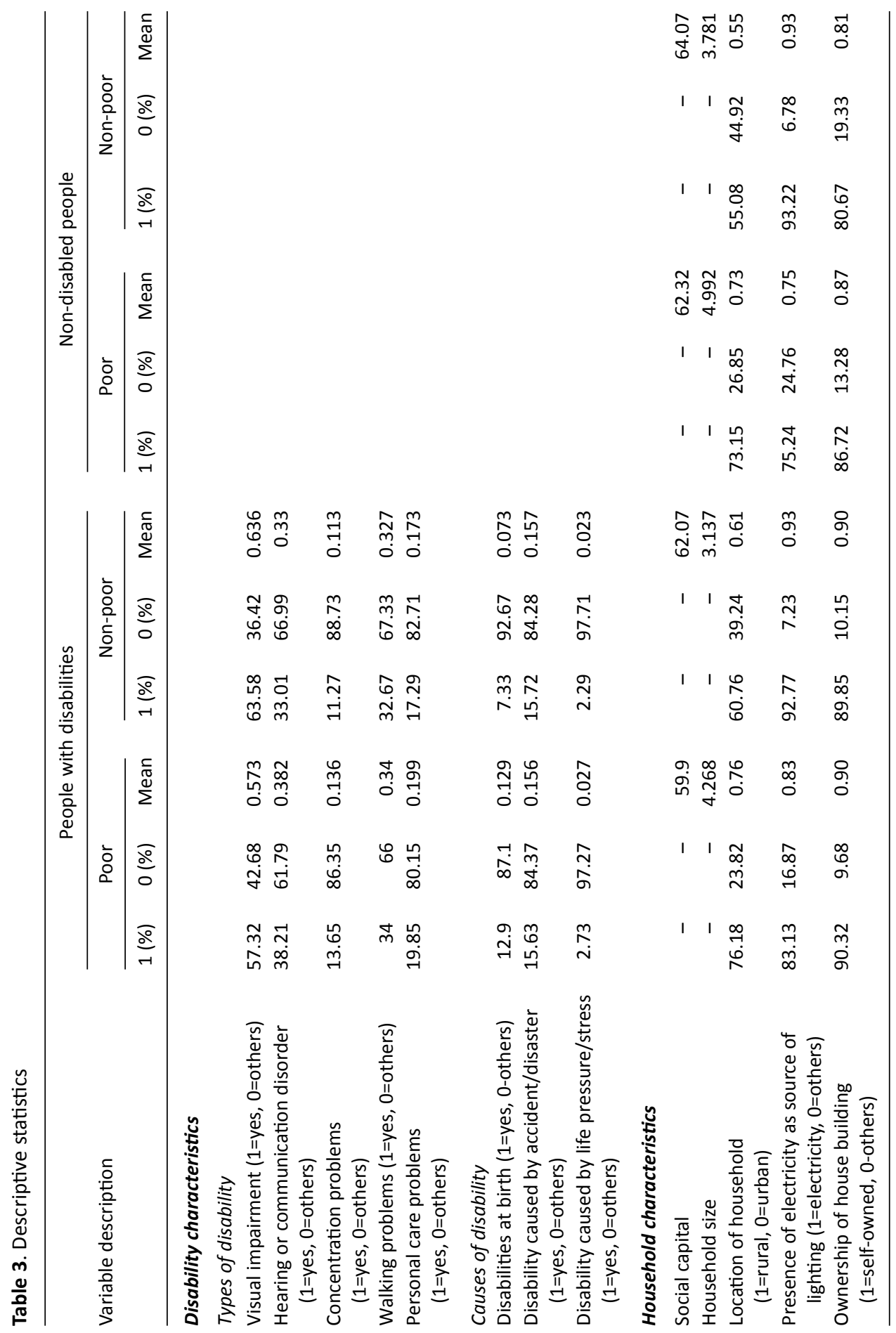




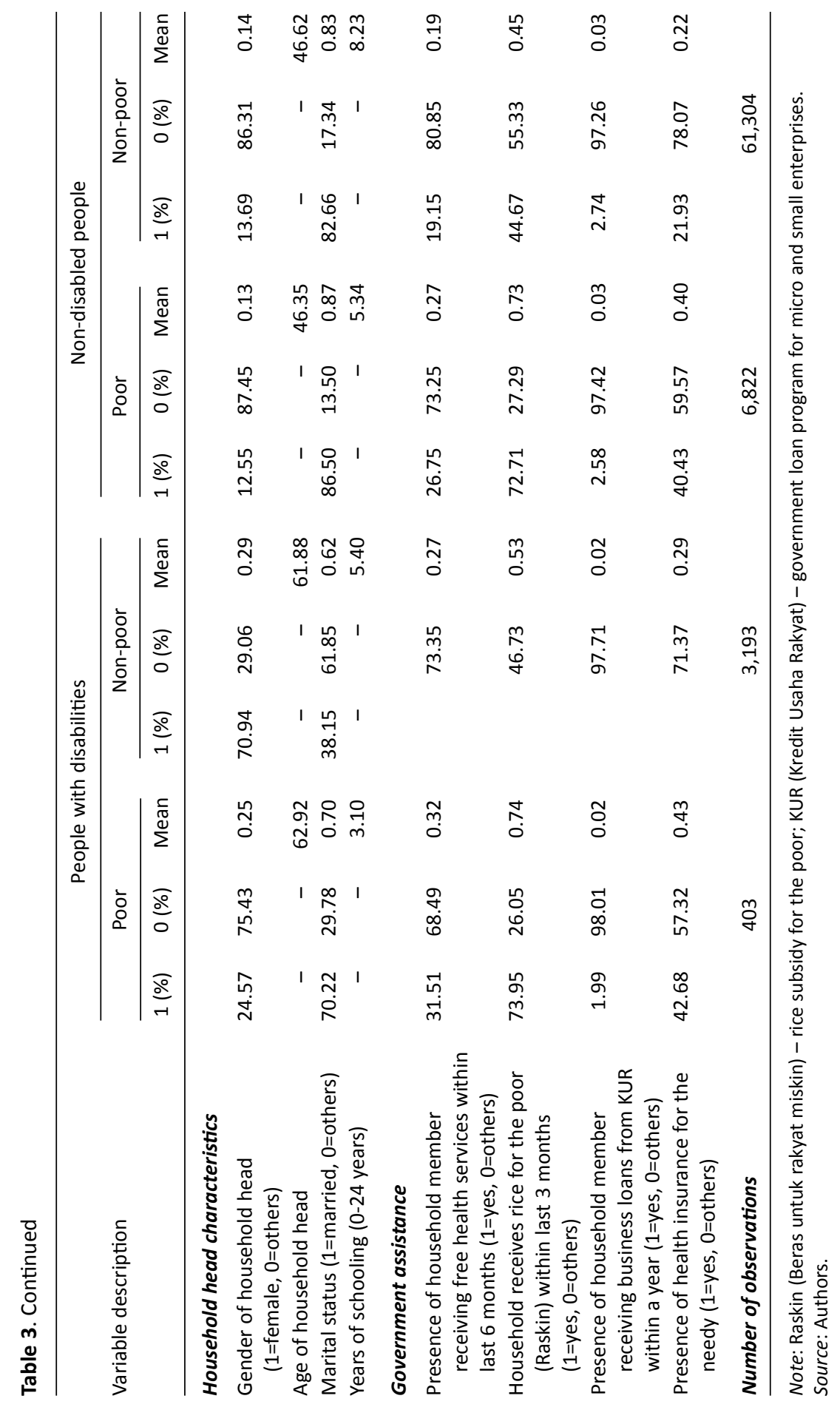




\subsection{Estimation Results}

Table 4 shows the econometric estimation results of Models 1 and 2, which analysed the relation between disability and poverty (indicated by the headcount index and the poverty gap index). Table 5 shows the estimation results of Models 3 and 4, which analysed the impact of persons' disability characteristics on poverty status and poverty gap index. The models were estimated using maximum likelihood estimation, with robust standard errors. All models show that the Wald chi-square statistics of log likelihood of the Logit and Tobit models are statistically significant, indicating that at least one of the covariates or independent variables affects the poverty status of households. Generally, the built Logit and Tobit models of poverty status (poverty gap index) show their consistency and robustness.

Table 4. Estimation results of models 1 and 2 (Sample: all households)

\begin{tabular}{|c|c|c|c|c|c|c|c|c|}
\hline \multirow[t]{3}{*}{ Variable } & \multicolumn{4}{|c|}{$\begin{array}{l}\text { Model 1: Logit model (Marginal effect) } \\
\text { (Poverty status) }\end{array}$} & \multicolumn{4}{|c|}{$\begin{array}{l}\text { Model 2: Tobit model } \\
\quad \text { (Poverty gap) }\end{array}$} \\
\hline & \multicolumn{2}{|c|}{ 1st Regression } & \multicolumn{2}{|c|}{ 2nd Regression } & \multicolumn{2}{|c|}{ 1st Regression } & \multicolumn{2}{|c|}{ 2nd Regression } \\
\hline & Coef. $\mathrm{R}$ & $\begin{array}{l}\text { Robust } \\
\text { S.E. }\end{array}$ & Coef. & $\begin{array}{l}\text { Robust } \\
\text { S.E. }\end{array}$ & Coef. & $\begin{array}{l}\text { Robust } \\
\text { S.E. }\end{array}$ & Coef. & $\begin{array}{l}\text { Robust } \\
\text { S.E. }\end{array}$ \\
\hline \multicolumn{9}{|l|}{ Disability characteristics } \\
\hline $\begin{array}{l}\text { Household head with PWD } \\
\text { (1=yes, } 0=\text { others) }\end{array}$ & $0.011^{* *}$ & 0.004 & $0.013^{* *}$ & 0.005 & $0.023^{* *}$ & 0.009 & $0.026^{* * *}$ & 0.009 \\
\hline \multicolumn{9}{|l|}{ Household characteristics } \\
\hline Social capital & & & $-0.001^{* * *}$ & 0.000 & & & $-0.002^{* * *}$ & 0.000 \\
\hline Size of household member & & & $0.032^{* * *}$ & 0.001 & & & $0.062^{* * *}$ & 0.001 \\
\hline Location (1=rural, 0=urban) & & & $0.017^{* * *}$ & 0.003 & & & $0.029^{* * *}$ & 0.004 \\
\hline Electricity (1=yes, $0=$ no access) & & & $-0.086^{* * *}$ & 0.003 & & & $-0.180^{* * *}$ & 0.006 \\
\hline $\begin{array}{l}\text { House ownership } \\
\qquad(1=\text { self-owned, } 0=\text { others })\end{array}$ & & & $-0.008^{* *}$ & 0.003 & & & $-0.0136^{* *}$ & ${ }^{*} 0.006$ \\
\hline \multicolumn{9}{|l|}{$\begin{array}{l}\text { Household head }(\mathrm{HH}) \\
\text { characteristics }\end{array}$} \\
\hline Gender ( 1 =female, $0=$ others) & & & $0.021^{* * *}$ & 0.005 & & & $0.048^{* * *}$ & 0.010 \\
\hline Age & & & $-0.001^{* * *}$ & 0.000 & & & $-0.002^{* * *}$ & 0.000 \\
\hline $\begin{array}{l}\text { Marital status } \\
\qquad(1=\text { married, } 0=\text { others })\end{array}$ & & & $0.017^{* * *}$ & 0.005 & & & $0.031^{* * *}$ & 0.010 \\
\hline Years of schooling & & & $-0.015^{* * *}$ & 0.000 & & & $-0.044^{* * *}$ & 0.009 \\
\hline Constant/Intercept & $-2.196^{* * *}$ & 0.013 & $-0.866^{* * *}$ & 0.121 & $-0.436^{* * *}$ & $* 0.005$ & $-0.148^{* * *}$ & 0.018 \\
\hline Prob $>C h i^{2} /$ Prob $>F$ & \multicolumn{2}{|c|}{0.0206} & \multicolumn{2}{|c|}{0.000} & \multicolumn{2}{|c|}{0.0146} & \multicolumn{2}{|c|}{0.0000} \\
\hline Pseudo $R^{2}$ & \multicolumn{2}{|c|}{0.0001} & \multicolumn{2}{|c|}{0.1602} & \multicolumn{2}{|c|}{0.0002} & \multicolumn{2}{|c|}{0.2304} \\
\hline Number of observations & \multicolumn{2}{|c|}{71,722} & \multicolumn{2}{|c|}{71,722} & \multicolumn{2}{|c|}{71,722} & \multicolumn{2}{|c|}{71,722} \\
\hline
\end{tabular}

Notes: Level of significance: ${ }^{*} \mathrm{p}<0.1,{ }^{*} \mathrm{p}<0.05, * * * \mathrm{p}<0.01$.

Tobit model: 64,497 left-censored observations, 7,225 uncensored observations, 0 right-censored observation.

Source: Authors. 
Models 1 and 2 significantly bear out the positive impact of disability to both poverty status and poverty gap index. As seen in Table 4, disabled-headed household is more likely to be poor by 1.3 percentage points and have a deeper poverty gap index by 2.6 percent. This result is consistent with Benfield (2008) and Kavanagh et al. (2015). Likewise, Yeo and Moore (2003) found that PWD are more likely to become poor due to three kinds of discriminations. Theoretically, the result follows Sen's capability approach theory, which asserts that PWD have lower capabilities due to the disadvantages that they experienced (Sen, 2009).

Model 3 and Model 4 attempt to discover the impact of disability characteristics of disabled headed household on poverty status and poverty gap index. The result in Table 5 points out that the types and causes of disabilities have similar impact on both poverty status and poverty gap index. In terms of types of disabilities, visually impaired household heads are less likely to become poor by 2.4 percentage points and tend to have lower poverty gap index by 4.1 percent compared to other types of disabilities after control variables are included. This result is in line with Smith's (2007) findings. Additionally, Didi Tarsidi, the former head of Indonesian Association of the Blind (PERTUNI), stated that the result may be due to the higher confidence of visually impaired people (Tarsidi, 2015). According to Tarsidi (2015), PWD who experience visual impairment could declare their disabilities more easily because they cannot see people underestimating or looking down upon them. As a result, visually impaired people will use their energy for more productive activities.

Another type of disability, which is self-care problem, has significant positive impact on poverty status after controlling for household and household head characteristics. Similar to the finding of Smith (2007), this study finds that a disabled household head with a self-care problem is more likely to have a poor household by 2.4 percentage points compared to other types of disabilities. PWD who have the inability to care for him/herself may find it very difficult to work or find jobs, so they are more likely to be poor. Moreover, PWD who have a self-care problem usually need others to help them do daily activities, and this may lead to additional costs, either direct or indirect (opportunity cost if one household member acts as personal caregiver).

Regarding causes of disability, the result shows that disabilities at birth has significant positive impact on both poverty status and poverty gap index, even before control variables are included. A household head whose disability appears since he/ she was born (having disabilities at birth) is 4.8 percentage points more likely to have a household below the poverty line and have deeper poverty gap index of about 7.8 percent. According to Yeo and Moore (2003), PWD experience three kinds of discrimination: institutional discrimination, physical environment discrimination and social discrimination. People with disabilities at birth may experience longer and greater discrimination in comparison with other people whose disability is caused by other factors. For example, a person with disabilities at birth may experience discrimination at home, school and workforce, while a disabled person whose disability is caused by an accident may only be discriminated in the workforce or may not experience any discrimination (due to compensation for accident at work). However, the result is not consistent according to the findings of Gouvier, Mayville and Sytsma-Jordan (2003) and Kavanagh et al. (2015). 
Table 5. Regression coefficients of models 3 and 4 (Sample of PWD only)

\begin{tabular}{|c|c|c|c|c|c|c|c|c|}
\hline \multirow[t]{3}{*}{ Variable } & \multicolumn{4}{|c|}{$\begin{array}{l}\text { Model 3: Logit model (Marginal effect) } \\
\text { (Poverty status) }\end{array}$} & \multicolumn{4}{|c|}{$\begin{array}{l}\text { Model 4: Tobit model } \\
\text { (Poverty gap) }\end{array}$} \\
\hline & \multicolumn{2}{|c|}{ 1st Regression } & \multicolumn{2}{|c|}{ 2nd Regression } & \multicolumn{2}{|c|}{ 1st Regression } & \multicolumn{2}{|c|}{ 2nd Regression } \\
\hline & Coef. & $\begin{array}{l}\text { Robust } \\
\text { S.E. }\end{array}$ & Coef. & $\begin{array}{l}\text { Robust } \\
\text { S.E. }\end{array}$ & Coef. $\mathrm{F}$ & $\begin{array}{l}\text { Robust } \\
\text { S.E. }\end{array}$ & Coef. & $\begin{array}{l}\text { Robust } \\
\text { S.E. }\end{array}$ \\
\hline \multicolumn{9}{|l|}{ Disability characteristics } \\
\hline \multicolumn{9}{|l|}{ Types of disability } \\
\hline $\begin{array}{l}\text { Visual Impairment } \\
\qquad(1=\text { yes, } 0=\text { others })\end{array}$ & -0.019 & 0.012 & $-0.024^{* *}$ & 0.012 & -0.027 & 0.022 & $-0.041^{* *}$ & 0.020 \\
\hline $\begin{array}{l}\text { Hearing or communication } \\
\text { disorder ( } 1=y e s, 0=\text { others) }\end{array}$ & 0.015 & 0.012 & 0.003 & 0.011 & 0.029 & 0.021 & 0.011 & 0.020 \\
\hline $\begin{array}{l}\text { Concentration problems } \\
\text { (1=yes, } 0=\text { others) }\end{array}$ & 0.019 & 0.019 & 0.011 & 0.018 & 0.045 & 0.034 & 0.024 & 0.032 \\
\hline $\begin{array}{l}\text { Walking problems } \\
\qquad(1=\text { yes, } 0=\text { others })\end{array}$ & -0.007 & 0.014 & -0.008 & 0.013 & -0.003 & 0.023 & -0.006 & 0.022 \\
\hline $\begin{array}{l}\text { Personal care problems } \\
\text { (1=yes, } 0=\text { others) }\end{array}$ & 0.017 & 0.016 & $0.024^{*}$ & 0.014 & 0.022 & 0.027 & 0.030 & 0.025 \\
\hline \multicolumn{9}{|l|}{ Causes of disability } \\
\hline Congenital ( $1=y e s, 0=$ others) & $0.061^{* * *}$ & 0.017 & $0.048^{* * *}$ & 0.017 & $0.109^{* * *}$ & ${ }^{*} 0.032$ & $0.078^{* *}$ & 0.031 \\
\hline $\begin{array}{l}\text { Accident/disaster } \\
\text { (1=yes, } 0=\text { others) }\end{array}$ & -0.002 & 0.016 & -0.005 & 0.015 & -0.001 & 0.029 & -0.010 & 0.027 \\
\hline $\begin{array}{l}\text { Pressure/stress } \\
\qquad(1=y e s, 0=\text { others })\end{array}$ & -0.002 & 0.040 & 0.004 & 0.040 & 0.013 & 0.071 & 0.034 & 0.066 \\
\hline \multicolumn{9}{|l|}{ Household characteristics } \\
\hline Social capital & & & $-0.001^{* * *}$ & 0.000 & & & $-0.003^{* * *}$ & 0.001 \\
\hline Size of household member & & & $0.030^{* * *}$ & 0.002 & & & $0.056^{* * *}$ & 0.005 \\
\hline Location (1=rural, 0=urban) & & & $0.033^{* * *}$ & 0.012 & & & $0.045^{* *}$ & 0.021 \\
\hline Electricity ( $1=y e s, 0=$ no access) & & & $-0.066^{* * *}$ & 0.015 & & & $-0.143^{* * *}$ & 0.027 \\
\hline $\begin{array}{l}\text { House Ownership } \\
\qquad(1=\text { self-owned, } 0=\text { others })\end{array}$ & & & $-0.038^{* * *}$ & * 0.017 & & & $-0.074^{* *}$ & 0.031 \\
\hline \multicolumn{9}{|l|}{ Household head characteristics } \\
\hline Gender ( $1=$ female, $0=$ others) & & & 0.019 & 0.020 & & & 0.022 & 0.034 \\
\hline Age & & & 0.0005 & 0.000 & & & 0.001 & 0.001 \\
\hline $\begin{array}{l}\text { Marital status } \\
\qquad(1=\text { married, } 0=\text { others })\end{array}$ & & & $0.052^{* *}$ & 0.020 & & & $0.087^{* * *}$ & 0.033 \\
\hline Years of schooling & & & $-0.016^{* * *}$ & 0.002 & & & $-0.028^{* * *}$ & 0.003 \\
\hline Constant/Intercept & $-2.095^{* * *}$ & 0.132 & $-1.623^{* * *}$ & 0.542 & $-0.437^{* * *}$ & 0.031 & $-0.237^{* * *}$ & 0.087 \\
\hline Prob $>C h i^{2} /$ Prob $>F$ & 0.00 & 012 & 0.00 & 000 & & 049 & 0.00 & 000 \\
\hline Pseudo $R^{2}$ & 0.00 & 092 & 0.14 & 414 & & 116 & 0.19 & 934 \\
\hline Number of observations & & 596 & 3,5 & 596 & & 596 & & 596 \\
\hline
\end{tabular}

Notes: Level of significance: ${ }^{*} \mathrm{p}<0.1,{ }^{* *} \mathrm{p}<0.05,{ }^{* * *} \mathrm{p}<0.01$.

Tobit model: 3193 left-censored observations, 403 uncensored observations, 0 right-censored observation.

Source: Authors. 
Household characteristic variables have similar sign and significance of coefficient in all four models. Households, both with and without disabled household head that have higher social capital are less likely to become poor and tend to have lower poverty gap index. This finding is in line with findings by Grootaert (1999) and Rupasingha and Goetz (2007). In terms of disability, Yeo and Moore (2003) stated that social discrimination is one of the factors that cause PWD to be more likely to become poor. The presence of social capital will eliminate social discriminations in society, so that it decreases the likelihood of PWD to become poor. Having access to electricity for lighting and status of ownership in terms of housing both show negative correlations with poverty status and poverty gap index of the household.

Meanwhile, household size and location in rural areas have positive correlations with poverty status and poverty gap index of both disabled-headed households and non-disabled-headed households. As the number of individuals in a household increases, the probability of being poor and the likelihood of having a higher poverty gap index may increase due to higher burden and expense faced by the household. This finding confirms some studies done by Bayudan-Dacuycuy and Lim (2013) and Lamichhane, Paudel and Kartika (2014). Another result shows that a household located in a rural area is more likely to become poor and have a higher poverty gap. The lower quantity and quality of infrastructure and the lesser amount of job opportunities available may be the reason for this finding.

Since disability characteristics of household heads in Models 1 and 2 are different from those of Models 3 and 4, the sign and significance of some coefficients of household head characteristic variable may show different results. In the first and second models, a female household head has higher probability of being poor and tends to have higher poverty gap index. This may result from gender discrimination, which usually affects females rather than males. This result is in line with Lamichhane, Paudel and Kartika (2014) and Pressman (2002) who found that a female headed household tends to be poorer. The result from the third and fourth models shows a similar sign, but is not significant. As described by Yeo and Moore (2003), PWD face some kinds of discriminations, and these discriminations may obscure gender discrimination, which is usually experienced by females.

The age of household heads has a significant negative correlation with poverty status and poverty gap index in Models 1 and 2. Meanwhile, the age of households has a positive correlation in the third and second models, but is not significant. According to Malik (1996), income per capita and age of household heads are assumed to have a positive relationship over the age bracket of 25 to 45 years, and a negative relationship beyond this bracket (beyond 45 years). This implies that the age of household heads will tend to have a lower probability of being poor if their age is within the bracket, and a higher probability of being poor if their age is beyond the bracket. Based on description of the data, the age of household heads in the sample used in the first and second models (disabled and non-disabled) have an almost equal proportion of age within and beyond the bracket: household heads with an age lower and equal to 45 is 49 percent and household heads with an age higher than 45 is 51 percent. In contrast to previous description of the data, the age of household heads in the sample used in the third and fourth models has an imbalanced proportion and tends toward the upper bracket: 
household heads with an age lower and equal to 45 is 13 percent and household heads with an age higher than 45 is 87 percent. The different sample sets may be the reason for the different sign of coefficient between the two results.

In all four models, marital status has significant positive correlation with poverty, which implies that a married household head tends to be poorer than a household head with some other marital status. As males tend to dominate as household heads, the married household head may face more burdens due to a higher number of dependents. This finding does not coincide with those of Dartanto and Nurkholis (2013) and Sekhampu (2013). Education coefficient in all four models shows significant negative impact between years of education and poverty, implying that the longer the schooling period of the household head, the lower the probability of being poor. Household heads with higher education may have a wider selection of jobs and thus a higher income potential.

\section{Concluding Remarks}

Policy discussions and the designing of poverty alleviation programs of PWD in Indonesia are always lagging behind due to a lack of data availability and low number of evidence-based researches. Consequently, the government still applies equal treatment to overcome the problem of poverty of PWD and non-disabled people even though PWD have disadvantages due to earning and conversion handicap that are not experienced by non-disabled people. Therefore, there is an urgent need to conduct a solid and rigorous study to support and mainstream PWD on the development agenda in Indonesia due to the fact that PWD is a part of Sustainable Development Goals (WHO, 2015).

This study, using the 2012 third quarter national-social economic survey (SUSENAS 2012 Q3), aims at examining the impacts of disability, types and sources of disabilities on a household's poverty status and the household's intensity of poverty (poverty gap index). Our estimation results from the Logistic and Tobit regressions confirm that a disabled household head is more likely to have poor household by 1.3 percentage points and have deeper poverty gap index by 2.6 percent. This coincides with the theory of capability approach (Sen, 2009), which asserted that PWD have lower capabilities due to a couple of disadvantages and later may lead to the lower economic condition of PWD. This finding suggests that the government should include people with disabilities in development agendas, including a poverty eradicating one.

In the case of the different types of disabilities and the different sources of disabilities, household heads that are visually-impaired are more likely to have a higher probability of being non-poor and have a lower poverty gap compared to other disabled-headed households. Meanwhile, a disabled household head who has a selfcare problem tends to have a higher probability of falling into poverty. Regarding causes of disability, a disabled household head who has disabilities at birth is more likely to fall below the poverty line for about 4.8 percentage points and have deeper poverty gap index of about 7.8 percent.

This study suggests that the amelioration of the poverty of PWD should be implemented mostly to people with a self-care problem and should target rehabilitative 
care, so that they may learn to take care of themselves and as a result have a lower probability of being poor. Moreover, disability deterrence may be conducted with a focus on the prevention of disability at birth through prenatal care - like increasing expectant mothers' nutrition, providing programs for intensive pregnancy health care, increase availability and distribution of birth attendants, etc. - as there is a positive relation between disabilities at birth and poverty. The presence of two such policies is expected to overcome the problems of poverty of PWD. In addition, the poverty alleviation policies for PWD and non-disabled people should be different and modified due to the special conditions experienced by PWD. Equality does not necessary mean same treatment since justice does not always mean equality, because different people have different needs.

\section{References}

Adioetomo, S., Mont, D., \& Irwanto. (2014). Persons with disabilities in Indonesia: Empirical facts and implications for social protection policies. Jakarta: Demographic Institute-Universitas Indonesia \& TNP2K.

Asogwa, B., Umeh, J., \& Okwoche, V. (2012). Estimating the determinants of poverty depth among the peri-urban farmers in Nigeria. Current Research Journal of Social Sciences, 4(3), 201-206.

Badan Pusat Statistik. (2012). National socioeconomic survey 2012 (SUSENAS). Jakarta: Author.

Badan Pusat Statistik. (2014). Perhitungan dan analisis kemiskinan makro Indonesia tahun 2014. Jakarta: Author.

Badan Pusat Statistik. (2017, May 30). Poverty and inequality. Retrieved from https://www.bps. go.id/subject/23/kemiskinan-dan-ketimpangan.html

Bayudan-Dacuycuy, C., \& Lim, J.A. (2013). Family size, household shocks and chronic and transient poverty in the Philippines. Journal of Asian Economics, 29(December), 101-112. https://doi. org/10.1016/j.asieco.2013.10.001

Benfield, W.A. (2008). Determinants of poverty and subjective well-being. Social and Economic Studies, 57(3/4), 1-51.

Benson, T., Chamberlin, J., \& Rhinehart, I. (2005). An investigation of the spatial determinants of the local prevalence of poverty in rural Malawi. Food Policy, 30(5-6), 532-550. https://doi. org/10.1016/j.foodpol.2005.09.004

Bordieri, J.E., \& Drehmer, D.E. (1988). Causal attribution and hiring recommendations for disabled job applicants. Rehabilitation Psychology, 33(4), 239-247. https://doi.org/10.1037/ h0091699

Burkhauser, R.V., Houtenville, A.J., \& Rovba, L. (2005). Rising poverty in the midst of plenty: The case of working-age people with disabilities over the business cycles of the 1980s and 1990s. Ithaca, NY: Rehabilitation Research and Training Center for Economic Research on Employment Policy for People with Disabilities, Cornell University.

Byrnes, A., Conte, A., Gonnot, J.-P., Larsson, L., Schindlmayr, T., Shepherd, N., ... Zarraluqui, A. (2007). From exclusion to equality: Realizing the rights of persons with disabilities. Geneva: United Nations.

Dartanto, T., \& Nurkholis. (2013). The determinants of poverty dynamics in Indonesia: Evidence from panel data. Bulletin of Indonesian Economic Studies, 49(1), 61-84. https://doi.org/10.10 80/00074918.2013.772939

Etim, N.A., Edet, G.E., \& Esu, B.B. (2009). Determinants of poverty among peri-urban Telferia occidentalis farmers in Uyo, Nigeria. Journal of Agriculture and Social Sciences, 5(1-2), 49-51. 
Florian, V. (1978). Employers' opinions of the disabled person as a worker. Rehabilitation Counseling Bulletin, 22(1), 38-43.

Foster, J., Greer, J., \& Thorbecke, E. (1984). A class of decomposable poverty measures. Econometrica, 52(3), 761-766. https://doi.org/10.2307/1913475

Gouvier, W.D., Mayville, S., \& Sytsma-Jordan, S. (2003). Patterns of discrimination in hiring job applicants with disabilities: The role of disability type, job complexity, and public contact. Rehabilitation Psychology, 48(3), 175-181. https://doi.org/10.1037/0090-5550.48.3.175

Grootaert, C. (1999). Social capital, household welfare and poverty in Indonesia (Local Level Institutions Working Paper No. 6). Washington, DC: The World Bank.

Gujarati, D., \& Porter, D. (2009). Basic econometrics, 5th Edition. New York: McGraw-Hill.

Halimatussadiah, A., Agriva, M., \& Nuryakin, C. (2015). Persons with disabilities (PWD) and labor force in Indonesia: A preliminary study (LPEM FEBUI Working Paper, No. 201403). Jakarta: Faculty of Economics and Business, University of Indonesia.

Harahap, R.R., \& Bustanuddin. (2015). Perlindungan hukum terhadap penyandang disabilitas menurut Convention on the Rights of Persons with Disabilities (CRPD). Jurnal Inovatif, 8(1), 17-29.

Kavanagh, A.M., Krnjacki, L., LaMontagne, A.D., Beer, A., Baker, E., \& Bentley, R. (2015). Intersections between disability, type of impairment, gender and socio-economic disadvantage in a nationally representative sample of 33,101 working-aged Australians. Disability and Health Journal, 8(2), 191-199. https://doi.org/10.1016/j.dhjo.2014.08.008

Lamichhane, K., Paudel, D.B., \& Kartika, D. (2014). Analysis of poverty between people with and without disabilities in Nepal (JICA-RI Working Paper No. 77). Tokyo: JICA Research Institute.

Long, J.S. (1997). Regression models for categorial and limited dependent variables. London: Sage Publishing.

Malik, S. (1996). Determinants of Rural Poverty in Pakistan: A Micro Study. The Pakistan Development Review, 35(2), 171-187.

McNeil, J. (2001). Americans with Disabilities: 1997. Washington, DC.: U.S. Department of Commerce.

Mitra, S., Posarac, A., \& Vick, B. (2011). Disability and Poverty in Developing Countries: A Snapshot from the World Health Survey. Washington, DC: The World Bank.

Pressman, S. (2002). Explaining the Gender Poverty Gap in Developed and Transitional Economies. Journal of Economic Issues, 36(1), 17-40.

Rupasingha, A., \& Goetz, S.J. (2007). Social and political forces as determinants of poverty: A spatial analysis. The Journal of Socio-Economics, 36(4), 650-671. https://doi.org/10.1016/j. socec.2006.12.021.

Sekhampu, T.J. (2013). Determinants of poverty in a South African township. Journal of Social Sciences, 34(2), 145-153. https://doi.org/10.1080/09718923.2013.11893126

Sen, A. (1993). Capability and well-being. In M. Nussbaum \& A. Sen, The Quality of Life (p. 30). Oxford: Oxford University Press.

Sen, A. (2000). Development as freedom. New York: Alfred A. Knopf, Inc.

Sen, A. (2009). The Idea of Justice. Cambridge: The Belknap Press of Harvard University Press.

Smith, D.L. (2007). The relationship of type of disability and employment status in the United States from the behavioral risk factor surveillance system. Journal of Rehabilitation, 73(2), 32-40.

Tarsidi, D. (2015, July 22). Faktor penyebab lebih tingginya kesejahteraan penyandang disabilitas penglihatan dibandingkan dengan penyandang disabilitas lainnya dan peran PERTUNI akan hal tersebut. (A. Bella, Interviewer).

World Health Organization. (2011). World report on disability. Geneva: WHO Library Cataloguingin-Publication Data. 
World Health Organization. (2015). Health in 2015: From MDGs, Millennium Development Goals to SDGs, Sustainable Development Goals. Geneva: WHO Library Cataloguing-in-Publication Data.

Yeo, R., \& Moore, K. (2003). Including disabled people in poverty reduction work: "Nothing about us, without us". World Development, 31(3), 571-590. https://doi.org/10.1016/S0305750X(02)00218-8.

Zaidi, A., \& Burchardt, T. (2003). Comparing incomes when needs differ: Equivalisation for the extra costs of disability in the UK (CASEpaper 64). London: Centre for Analysis of Social Exclusion, London School of Economics. 